\title{
Korelasi Tekanan Parsial Oksigen Dengan Jumlah Eritrosit Berinti Pada Neonatus Hipoksemia
}

Cici Julia Sri Dewi ${ }^{1}$, Rismawati Yaswir ${ }^{2}$, Desywar ${ }^{2}$

\begin{abstract}
Abstrak
Tekanan parsial oksigen darah arteri $\left(\mathrm{PaO}_{2}\right)$ sebagai penanda oksigenasi dalam darah arteri dapat diukur dari analisis gas darah. Hipoksemia ditandai dengan $\mathrm{PaO}_{2}<80 \mathrm{mmHg}$. Hipoksia menimbulkan peningkatan jumlah Eritrosit Berinti (EB) sebagai kompensasi kebutuhan oksigen yang meningkat. Tujuan penelitian ini adalah menentukan korelasi $\mathrm{PaO}_{2}$ dengan jumlah EB pada neonates hipoksemia di RSUP Dr M Djamil Padang. Penelitian analitik dengan rancangan potong lintang dilakukan terhadap neonatus yang dirawat di RSUP Dr M Djamil Padang dengan $\mathrm{PaO}_{2}<$ $80 \mathrm{mmHg}$. Penelitian dilaksanakan Februari sampai Agustus 2016. Pemeriksaan $\mathrm{PaO}_{2}$ dilakukan melalui analisis gas darah dan EB dihitung dengan melihat sediaan hapus darah tepi melalui mikroskop. Hasil pemeriksaan dianalisis menggunakan korelasi Spearman dan bermakna bila $p<0,05$. Hasil penelitian terhadap 30 sampel didapatkan rerata $\mathrm{PaO}_{2}(\mathrm{mmHg})$ pada hipoksemia ringan dan hipoksemia sedang-berat berturut-turut 71,40(5,36), 48,67(12,53) dan rerata EB/100leukosit 11,53(10,43), 26,87(15,25). Berdasarkan analisis korelasi Spearman didapatkan nilai r: $-0,257$ pada hipoksemia ringan. Nilai $\mathrm{r}$ : $-0,280$ pada hipoksemia sedang-berat. Korelasi $\mathrm{PaO}_{2}$ dengan EB berkorelasi lemah dan tidak bermakna secara statistik. Hasil $\mathrm{PaO}_{2}$ dengan EB berkorelasi lemah dan tidak bermakna secara statistik. Penelitian lebih lanjut dengan tambahan parameter lain seperti $\mathrm{pH}, \mathrm{pCO}_{2}$ dan menghubungkan lama hipoksemia atau hipoksia dengan jumlah EB pada neonatus.
\end{abstract}

Kata kunci: hipoksemia, $\mathrm{PaO}_{2}$, eritrosit berinti

\begin{abstract}
Partial pressure of oxygen $\left(\mathrm{PaO}_{2}\right)$ in arterial blood determined from blood gas analyze, hypoxemia considered if $\mathrm{PaO}_{2}<80 \mathrm{mmHg}$. The number of nucleated red blood cells (nRBCs) increases to compensate hypoxia. The objective of this study was to assess correlation between $\mathrm{PaO}_{2}$ and $n R B C$ s in hypoxemia neonates. This cross-sectional analytic studies was conducted in Dr M Djamil Hospital to inpatients subject with $\mathrm{PaO}_{2}<80 \mathrm{mmHg}$ from February-August 2016. Level of $\mathrm{PaO}_{2}$ was analyzed by blood gas measured and nRBCs were determined by blood smears. Spearman's test was used to analyze statistic and considered significant if $\mathrm{p}<0.05$. Mean of $\mathrm{PaO}_{2}(\mathrm{mmHg}) 71.40(5.36), 48.67(12.53)$, and $n R B C 11.53$ and 26.87 per 100 white blood cell (WBC) for mild hypoxemia and moderat hypoxemia respectively. Spearman's correlation test showed $r$ : -0.257 for mild hypoxemia, $r$-0.280 for moderate hypoxemia. There is weakly correlation between $\mathrm{PaO}_{2}$ and $n R B C$ s and statistically not significant. There is weakly correlation between $\mathrm{PaO}_{2}$ and $n R B C s$ and statistically not significant. Future studies are needed to assess correlation between $\mathrm{pH}, \mathrm{pCO}_{2}$, longterm hypoxemia/hypoxia and $n R B C s$
\end{abstract}

Keywords: hypoxemia, $\mathrm{PaO}_{2}$, nucleated red blood cells

Affiliasi penulis: 1. Program Pendidikan Dokter Spesialis-1 Patologi Klinik Fakultas Kedokteran Universitas Andalas (FK Unand), 2. Bagian Patologi Klinik FK Unand

Korespondensi: Cici Julia Sri Dewi, Email: nawafil0401@gmail.com Telp: 081340747733

\section{PENDAHULUAN}

Hipoksemia adalah suatu kondisi turunnya kandungan oksigen $\left(\mathrm{O}_{2}\right)$ di dalam darah arteri.Hipoksia adalah kondisi tidak adekuatnya suplai $\mathrm{O}_{2}$ ke jaringan.Hipoksia dapat disebabkan oleh hipoksemia atau gangguan suplai darah ke jaringan. Hipoksemia 
dapat disebabkan oleh gangguan oksigenasi, anemia atau penurunan afinitas hemoglobin $(\mathrm{Hb})$ terhadap $\mathrm{O}_{2}$.Gangguan oksigenasi adalah hipoksemia yang dihasikan dari rendahnya transfer $\mathrm{O}_{2}$ dari paru ke aliran darah, yang ditandai dengan rendahnya tekanan parsial $\mathrm{O}_{2}\left(\mathrm{PaO}_{2}<80 \mathrm{mmHg}\right)^{1,2}$

Tekanan parsial menggambarkan tekanan suatu gas terlarut terhadap tekanan total gas campuran (seperti tekanan gas oksigen terhadap total tekanan gas campuran di dalam udara). Tekanan parsial oksigen darah arteri sebagai penanda oksigenasi dalam darah arteri dapat diukur dari analisis gas darah. ${ }^{1,2,3}$

Hipoksia menyebabkan kerusakan organ multiple dan jika tidak diterapi dengan baik bias berakibat kematian. Hipoksia menimbulkan peningkatan jumlah Eritrosit Berinti (EB) melalui mekanisme mediasi eritropoietin sebagai kompensasi dari kebutuhan oksigen yang meningkat.Eritropoeisis yang meningkat melepaskan eritrosit imatur kesirkulasi darah. ${ }^{4,5,6}$

Eritrosit berinti secara umum terlihat di aliran darah neonatus.Jumlah EB pada neonates cukup bulan non asfiksia bervariasi, tetapi jarang lebih dari 10 EB per 100 leukosit. Jumlah EB akan meningkat pada keadaan hipoksia intrauterine melalui mekanisme peningkatan produksi eritropoietin., Jumlah EB pada neonates hipoksemia merupakan predictor terjadinya perdarahan intraventrikular, distress pernapasan, dan kematian neonatus. ${ }^{9,10}$

Penelitian lain tentang $\mathrm{PaO}_{2}$ dengan $\mathrm{EB}$ dan prognosis. Kesimpulan yang didapatkan adalah ditemukan EB pada penurunan nilai $\mathrm{PaO}_{2}$ dan menunjukkan prognosis yang buruk pada neonatus. ${ }^{11}$ Hasil penelitian di Jakarta mendapatkan hubungan yang bermakna antara jumlah EB dengan saturasi oksigen $\left(\mathrm{SaO}_{2}\right)$ sehingga merekomendasikan pemeriksaan EB untuk melihat hipoksia jika tidak tersedia alat pemeriksaan $\mathrm{SaO}_{2}$, mengingat akibat yang ditimbulkan oleh keadaan hipoksia sangat berat. $^{12}$

Penelitian lainnya tentang hubungan EB dengan neonates asfiksia akut dengan kesimpulan tidak semua asfiksia akut menimbulkan peningkatan EB. ${ }^{13,14}$ Penelitian tentang eritrosit berinti pada neonatus dengan hipoksemia belum pernah dilakukan di RSUP Dr M Djamil Padang. Keadaan ini menyebabkan penulis tertarik untuk mengetahui korelasi $\mathrm{PaO}_{2}$ dengan jumlah eritrosit berinti pada neonates hipoksemia di RSUP Dr. M Djamil Padang.

Penelitian ini bertujuan untuk menentukan korelasi tekanan parsial oksigen dengan jumlah eritrosit berinti pada neonates hipoksemia di RSUP Dr. M Djamil Padang.

\section{METODE}

Penelitian ini merupakan analitik korelatif dengan desain potong lintang. Populasi penelitian adalah neonatus yang melakukan pemeriksaan Analisis Gas Darah (AGD) di instalasi Laboratorium Sentral RSUP Dr. M. Djamil Padang dengan $\mathrm{PaO}_{2}<80$ $\mathrm{mmHg}$ pada bulan Februari sampai Agustus 2016. Kriteriai inklusi yaitu neonatus lahir matur dengan $\mathrm{PaO}_{2}<80 \mathrm{mmHg}$ dengan pemeriksaan $A G D$ yang pertama. Kriteria eksklusi neonatus dengan $\mathrm{Hb}<$ $13 \mathrm{~g} / \mathrm{dl}$. Semua yang memenuhi kriteria inklusi dan eksklusi diambil sebagai sampel dan dari rumus besar sampel didapatkan jumlah sampel minimal 14. Sampel hipoksemia ringan $\left(\mathrm{PaO}_{2}<80 \mathrm{mmHg}\right)$ dibedakan dengan hipoksemia sedang sampai berat $\left(\mathrm{PaO}_{2}<\right.$ $60 \mathrm{mmHg}$ ), sehingga didapatkan sampel sebanyak 30 yang memenuhi kriteria inklusi dan eksklusi.

Bahan pemeriksaan penelitian ada dua yaitu darah arteri bilas heparin dan darah vena dengan antikoagulan EDTA. Prosedur kerja yang dilakukan adalah pemeriksaan analisis gas darah dan sediaan hapus darah tepi. Pemeriksaan tersebut akan memberikan data $\mathrm{PaO}_{2}$, selanjutnya jika hasil $\mathrm{PaO}_{2}<$ $80 \mathrm{mmHg}$ dihitung jumlah EB pada sediaan hapus darah tepi. Perhitungan EB dilakukan oleh dua orang untuk melihat presisi hasil.

Uji normalitas data menggunakan uji ShapiroWilk, jika data terdistribusi normal menggunakan uji korelasi Pearson, jika data terdistribusi tidak normal menggunakan uji korelasi Spearman. Data penelitian dianalisis menggunakan program komputer dan ditampilkan dalam bentuk table distribusi frekuensi. Hasil dianggap mempunyai korelasi kuat apabila nilai mendekati 1. Kemaknaan secara statistik ditentukan jika $\mathrm{p}<0,05$. 
HASIL

Tabel 1. Interpretasi koefisien korelasi nilai $r$

\begin{tabular}{ll}
\hline Interval Koefisien & Tingkat Hubungan \\
\hline $0,800-1,000$ & Sangat Kuat \\
$0,600-0,799$ & Kuat \\
$0,400-0,599$ & Cukup Kuat \\
$0,200-0,399$ & Lemah \\
$0,000-0,199$ & Sangat Lemah \\
\hline
\end{tabular}

Selama periode Februari sampai Agustus 2016 didapatkan 30 sampel yang memenuhi kriteria inklusi dan kriteria hipoksemia ringan, sedang sampai berat sebanyak 15 sampel masing-masingnya. Karakteristik subjek penelitian disajikan pada tabel 2 (hipoksemia ringan) dan tabel 3 (hipoksemia sedang-berat).

Tabel 2. Karakteristik subjek penderita hipoksemia ringan

\begin{tabular}{lcc}
\hline \multicolumn{1}{c}{ Variabel } & Rerata (SD) & $\mathbf{n ( \% )}$ \\
\hline Jenis Kelamin & & $7(46,7)$ \\
Laki-laki & & $8(53,3)$ \\
Perempuan & & \\
Umur (hari) & $6,4(7,5)$ & \\
\hline
\end{tabular}

Jenis kelamin pasien yang terbanyak adalah perempuan yaitu 8 orang (53,3\%). Umur pasien berkisar antara 1 hari sampai 28 hari dengan rerata $6,40(7,5)$ hari.

Tabel 3. Karakteristik subjek penderita hipoksemia sedang-berat

\begin{tabular}{ccc}
\hline Variabel & Rerata(SD) & $\mathbf{n}(\%)$ \\
\hline Jenis Kelamin & & $5(33,3)$ \\
Laki-laki & & $10(66,7)$ \\
Perempuan & & \\
Umur (tahun) & $10,0(8,324)$ & \\
\hline
\end{tabular}

Jenis kelamin pasien yang terbanyak adalah perempuan yaitu 10 orang (66,7\%). Umur pasien berkisar antara 2 hari sampai 28 hari dengan rerata $10,00(8,324)$ hari.
Tabel 4. Hasil pemeriksaan $\mathrm{PaO}_{2}$ dan eritrosit berinti pada hipoksemia ringan

\begin{tabular}{rcl}
\hline Variabel & Rerata(SD) & Rentang \\
\hline $\mathrm{PaO}_{2}<80 \mathrm{mmHg}$ & $71,40(5,36)$ & $60-78$ \\
Eritrosit Berinti & $11,53(10,43)$ & $0-32$ \\
$/ 100$ leukosit & & \\
\hline
\end{tabular}

Hasil dari hipoksemia ringan didapatkan nilai $\mathrm{PaO}_{2}$ dari $60 \mathrm{mmHg}$ sampai $78 \mathrm{mmHg}$ dengan rerata $71,40(5,36) \mathrm{mmHg}$. Jumlah EB didapatkan dari 0 sampai 32 per 100 leukosit dengan rerata 11,53 $(10,43)$ per 100 leukosit.

Tabel 5. Hasil pemeriksaan $\mathrm{PaO}_{2}$ dan eritrosit berinti pada hipoksemia sedang-berat

\begin{tabular}{lcc}
\hline Variabel & Rerata(SD) & Rentang \\
\hline $\mathrm{PaO}_{2}<80 \mathrm{mmHg}$ & $48,67(12,53)$ & $18-62$ \\
Eritrosit Berinti & $26,87(15,25)$ & $0-46$ \\
\multicolumn{2}{l}{$/ 100$ Leukosit } & \\
\hline
\end{tabular}

Hasil dari hipoksemia sedang-berat didapatkan nilai $\mathrm{PaO}_{2}$ dari $18 \mathrm{mmHg}$ sampai $62 \mathrm{mmHg}$ dengan rerata $48,67(12,53) \mathrm{mmHg}$. Jumlah EB didapatkan dari 0 sampai 46 per 100 leukosit dengan rerata 26,87 $(15,25)$ per 100 leukosit.

Tabel 6. Korelasi $\mathrm{PaO}_{2}$ dengan eritrosit berinti

\begin{tabular}{ll}
\hline Kategori $(\mathbf{n}=\mathbf{1 5})$ & $\mathbf{P a O}_{\mathbf{2}}$ dengan EB \\
\hline Hipoksemia Ringan & $\mathrm{r}=-0,257$ \\
Hipoksemia Sedang-Berat & $\mathrm{p}=0,355$ \\
& $\mathrm{r}=-0,280$ \\
& $\mathrm{p}=0,312$ \\
\hline
\end{tabular}

Tabel 6 menampilkan korelasi antara $\mathrm{PaO}_{2}$ dengan EB. Didapatkan korelasi lemah dan tidak bermakna secara statistik dengan koefisien korelasi ( $r$ ) dan nilai p pada hipoksemia ringan dan hipoksemia sedang - berat secara berturut; $r=-0,257, p=0,355$, $r=-0,280, p=0,312$. Karakteristik subjek penelitian hipoksemia ringan dan hipoksemia sedang-berat didapatkan perempuan lebih banyak dibandingkan laki-laki dengan hasil secara berturut (53,3\%), $(66,7 \%)$ dan usia berkisar 1 sampai 28 hari dengan rerata $6,40(7,5)$ dan $10,00(8,324)$. 
Data hasil penelitian ini terdistribusi tidak normal, sehingga data diuji dengan korelasi Spearman. Penelitian ini mendapatkan korelasi lemah dan tidak bermakna secara statistik, karena hipoksemia pada beberapa pasien belum mencapai hipoksia. Hasil $\mathrm{PaO}_{2} 60-79 \mathrm{mmHg}$ didapatkan jumlah EB (per 100 leukosit) dari 0 sampai 32, pada satu sampel dengan $\mathrm{PaO}_{2} 60 \mathrm{mmHg}$ tidak ditemukan $\mathrm{EB}$, dan jumlah EB 30 didapatkan pada $\mathrm{PaO}_{2} 78 \mathrm{mmHg}$, pada hipoksemia sedang-berat $\left(\mathrm{PaO}_{2} 18\right.$ - 59) satu sampel dengan $\mathrm{PaO}_{2} 54 \mathrm{mmHg}$ tidak ditemukan $\mathrm{EB}$, dan $\mathrm{PaO}_{2} 55 \mathrm{mmHg}$ ditemukan jumlah EB 43. Koefisien korelasi pada hipoksemia sedang-berat sedikit lebih tinggi $(r=-0,280, p=0,312)$ dari pada hipoksemia ringan $(r=-0,257, p=0,355)$.

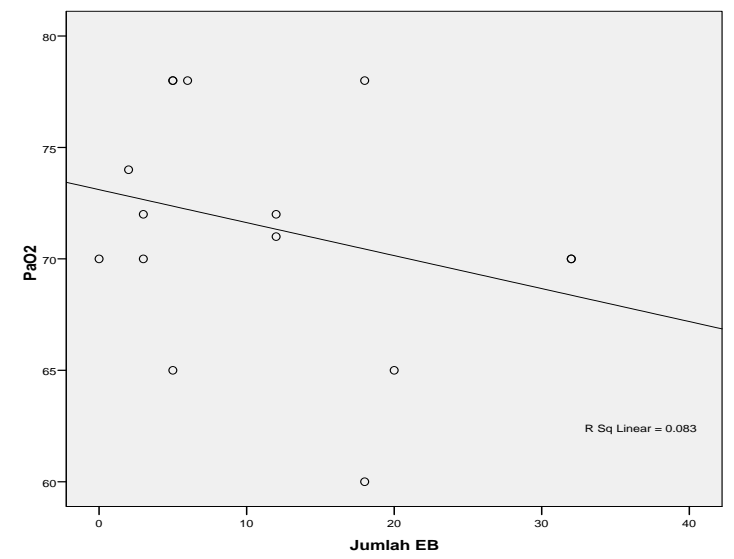

Gambar 1. Diagram Scatter plot pada hipoksemia ringan.

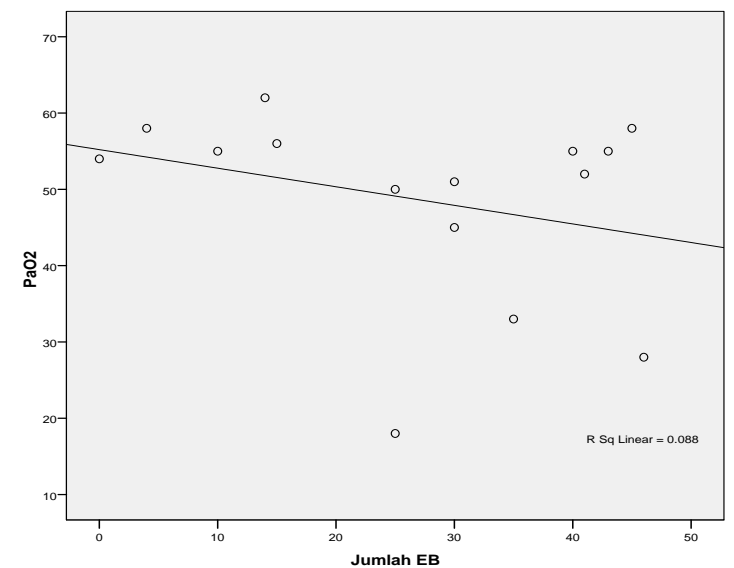

Gambar 2. Diagram Scatter plot pada hipoksemia sedang-berat.

\section{PEMBAHASAN}

Persentase peningkatan EB dengan penurunan $\mathrm{PaO}_{2}$ pada hipoksemia ringan dan hipoksemia sedang-berat secara berturut $66,7 \%$ dan $86,7 \%$. Hal ini sejalan dengan penelitian lain yang meneliti tentang $\mathrm{PaO}_{2}$ dengan $\mathrm{EB}$ dan prognosis. Kesimpulan yang didapatkan adalah ditemukan EB pada penurunan nilai $\mathrm{PaO}_{2}$ dan menunjukkan prognosis yang buruk pada neonatus. Penelitian lain menyimpulkan bahwa tidak semua asfiksia akut meningkatkan EB. ${ }^{11,13}$

Penelitian sebelumnya di Jakarta mendapatkan hubungan yang bermakna antara jumlah EB dengan penurunan saturasi oksigen pada bayi baru lahir. Hal ini menggambarkan peningkatan eritropoietin pada bayi asfiksia. $^{12}$ Penelitian lain menghubungkan hipoksia akut dan kronik dengan jumlah EB, didapatkan hasil bermakna peningkatan jumlah EB dengan hipoksia kronik. Hal ini menunjukkan peningkatan eritropoietin lebih banyak terjadi pada neonatus yang hipoksia kronik. ${ }^{16}$

Hipoksia disebabkan oleh hipoksemia. Hipoksemia yang tidak segera diatasi menyebabkan hipoksia. Hipoksia merangsang hypoxia induced factor-1 (HIF-1) yang berkaitan dengan proses aktivasi transkripsi gen eritropoietin sehingga terjadi peningkatan jumlah EB. ${ }^{15}$ Hasil penelitian ini didapatkan berkorelasi lemah, mungkin hipoksemia pada beberapa pasien belum sampai menyebabkan hipoksia sehingga belum terjadi peningkatan eritropoietin, sehingga didapatkan hasil $\mathrm{PaO}_{2}$ rendah (18 - $54 \mathrm{mmHg}$ ) namun EB tidak banyak bahkan tidak ada, sedangkan hasil $\mathrm{PaO}_{2}$ yang tidak terlalu rendah (70-79 mmHg) bisa ditemukan jumlah EB yang banyak, jika disesuaikan dengan teori diatas kemungkinan hal ini berhubungan dengan lama kejadian hipoksemianya.

Keterbatasan penelitian ini adalah tidak menilai parameter lain dari analisis gas darah seperti penurunan $\mathrm{pH}$ dan peningkatan tekanan karbondioksida $\left(\mathrm{pCO}_{2}\right)$ yang merupakan gambaran hipoksia. Lama rawatan dan kejadian hipoksemia juga tidak diketahui oleh peneliti. 


\section{SIMPULAN}

Hasil $\mathrm{PaO}_{2}$ dengan jumlah $\mathrm{EB}$ berkorelasi lemah dan tidak bermakna secara statistik pada neonatus hipoksemia.

\section{DAFTAR PUSTAKA}

1. Story DA. Bench to bedside review: a brief history of clinical acid- base. Crit Care. 2004;8: 253-8.

2. Carraro P, Plebani M. Error in A state laboratory: types and frequencies 10 years later. Clin Chem. 2007.53(7):1338-42.

3. Budak YU, Huisal K, Polat M. Use of blood gas analizer and a laboratory autoanalyzer in routine practice to measure electrolytes in intensive care unit patients. BMC Anesthesiol. 2012;12:17.

4. Dollberg S, Fainaru O, Mimouni FB, Shenhav M, Lessing BJ, Kupferminc M. Effect of passive smoking in pregnancy on neonatal nucleated red blood cells. Pediatrics. 2000;106:34.

5. Manoe V, Amir I. Gangguan fungsi multi organ pada bayi asfiksia berat. Sari Pediatri. 2005; 5: 72-8.

6. Dharmasetiawani N. Asfiksia dan resusitasi bayi baru lahir. Dalam: Kosim MS, Yunanto A, Dewi R, Sarosa G, Usman A, editor (penyunting). Buku ajar neonatologi. Jakarta: IDAI. 2008:103-25.

7. Gruslin A, Perkins SH, Manchanda R, Fleming N, Clinch JJ. Maternal smoking and fetal erythropoietin levels. Obstet Gynecol. 2000; 95: 561-4.

8. Perri T, Ferber A, Digli A, Rabizadeh E, Weissmann-Brenner A, Divon MY. Nucleated red blood cells in uncomplicated prolonged pregnancy. Obstet Gynecol. 2004;104:372-6.
9. Minior VK, Shatzkin E, Divon MY. Nucleated red blood cell count in the differentiation of fetuses with pathologic growth restriction from healthy small-forgestational-age fetuses. Am J Obstet Gynecol. 2000;182: 11079 .

10. Ghosh B, Mittal S, Kuman S, Dadhwal V. Prediction of perinatal asphyxia with nucleated red blood cells in cord blood of newborns. Int $\mathrm{J}$ Gynecol Obstet. 2003;81:267-71.

11. Kuert S, Tim Holland-Letz, Friese J, Stachon A. Association of nucleated red blood cells in blood and arterial oxygen partial tension. Clinical Chemistry and Laboratory Medicine.2010;49(2: 257-63.

12. Sarosa GI, Farid A, Rahmadi, Kosim MS, Kamilah $B$, Rahardjani. Correlation between nucleated red blood cells and pulse oxygen saturation in neonatal asphyxia. Paediatric Indonesia. 2014;54(6):314-7.

13. Fox $\mathrm{H}$. The incidence and significance of nucleated erythrocytes in the fetal vessels of the mature human placenta. J. Obstet Gynaecol $\mathrm{Br}$ Commonw.1997;74:40-3.

14. Schaer C. Prognostik value of NRBC in critically ill children in Swiss medical weekly. 2014;144 w13944:1-7.

15. Kaplan NM. Clinical haemotology. Philadelphia: Lipincott Williams \& Wilkins. 2006. Volume 10.hlm. 11-26.

16. Leikin E, Verma U, Klein S. Relationship between neonatal nucleated red blood cell counts and hypoxic-ischemic injury. Obstet Gynecol. 1996. Volume 87.hlm. 439-43. 